\title{
ANALISIS PRINSIP KEADILAN TENTANG SYARAT MENJADI ANGGOTA LEGISLATIF BAGI KEPALA DESA BERDASARKAN UNDANG - UNDANG NOMOR 7 TAHUN 2017 DAN PERATURAN KOMISI PEMILIHAN UMUM NOMOR 20 TAHUN 2018
}

\author{
Muhammad Sayuni' ${ }^{1}$, Elidar Sari ${ }^{2}$, Sulaiman ${ }^{3}$ \\ ${ }^{1}$ Mahasiswa S2 Hukum Tata Negara, Program Studi Magister Hukum \\ ${ }^{2}$ Dosen Hukum Tata Negara, Program Studi Magister Hukum, Fakultas Hukum \\ ${ }^{3}$ Dosen Hukum Tata Negara, Program Studi Magister Hukum, Fakultas Hukum \\ elidarsari@unimal.ac.id \\ Universitas Malikussaleh, Komplek Kampus Bukit Indah Jalan Jawa, \\ Padang Sakti, Kota Lhokseumawe Provinsi Aceh
}

\begin{abstract}
General Election is a means of implementing people's sovereignty which is carried out directly, freely, secretly, honestly and fairly based on the Pancasila and the 1945 Constitution of the Republic of Indonesia. Implementation of Elections is the implementation of the stages of elections which are carried out freely, fairly, and honestly. The purpose of this study is to analyze the principle of justice in the requirements to become a legislative member for the Village Head based on Law Number 7 of 2017 and Election Commission Regulation Number 20 of 2018. The results of the study showed that the first election held in 2019 did not implement the principles of justice in terms of the legislative candidate for the Village Head. The public can provide legal certainty for the implementation of the 2019 Election law. It is recommended to the General Election Commission to revise the Election Commission Regulation regarding the nomination of members of the DPR, Provincial DPRD, and Regency / City DPRD specifically in the requirements for candidates for the Village Head in Article 8 paragraph 1 letter $b$ number 6 point b, to guarantee the rights of citizens and fulfill the principles of justice.
\end{abstract}

Keywords: Justice, Legislative Members, Village Heads.

\section{Intisari}

Pemilihan Umum adalah sarana pelaksanaan kedaulatan rakyat yang dilaksanakan secara langsung, bebas, rahasia, jujur, dan adil berdasarkan Pancasila dan UndangUndang Dasar Negara Republik Indonesia Tahun 1945. Penyelenggaraan Pemilu adalah pelaksanaan tahapan Pemilu yang dilaksanakan secara bebas, adil, dan jujur. Tujuan penelitian ini adalah untuk menganalisis asas keadilan dalam persyaratan menjadi anggota legislatif bagi Kepala Desa berdasarkan Undang-Undang Nomor 7 Tahun 2017 dan Peraturan KPU Nomor 20 Tahun 2018. Hasil penelitian menunjukkan bahwa pemilihan pertama yang diselenggarakan pada tahun 2019 tidak menerapkan prinsip keadilan dalam hal calon legislatif Kepala Desa. Masyarakat 
dapat memberikan kepastian hukum atas pelaksanaan UU Pemilu 2019. Disarankan kepada KPU untuk merevisi Peraturan KPU tentang pencalonan anggota DPR, DPRD provinsi, dan DPRD kabupaten/kota khusus dalam persyaratan bakal calon Kepala Desa dalam Pasal 8 ayat 1 huruf $b$ angka 6 huruf $b$, untuk menjamin hak-hak warga negara dan memenuhi prinsip-prinsip keadilan.

\section{Kata kunci: Keadilan, Anggota Legislatif, Kepala Desa}

\section{Pendahuluan}

Dewasa ini Pemilihan Umum (Pemilu) telah menjadi bagian tak terpisahkan bagi negara-negara penganut demokrasi. Pemilu menjadi mekanisme dalam proses pergantian jabatan, khususnya di dua cabang kekuasaan, yakni di lembaga legislatif dan lembaga eksekutif. Seiring perkembangan zaman, pemilu telah berubah menjadi sistem tersendiri yang selanjutnya melahirkan berbagai corak, model, dan cara yang disesuaikan dengan sistem pemerintahan negara masing-masing. Di negara penganut sistem pemerintahan presidensial, model pemilu akan berbeda dengan negara penganut sistem pemerintahan parlementer. Bahkan, negara-negara yang sistem pemerintahannya sama pun, model pemilu atau untuk memilih siapa pemilu juga dapat berbeda. ${ }^{1}$

Sistem keadilan pemilu merupakan instrumen penting untuk menegakkan hukum dan menjamin sepenuhnya penerapan prinsip demokrasi melalui pelaksanaan pemilu yang bebas, adil, dan jujur. Sistem keadilan pemilu dikembangkan untuk mencegah dan mengidentifikasi ketidak beresan pada pemilu, sekaligus sebagai sarana dan mekanisme untuk membenahi ketidak beresan tersebut dan memberikan sanksi kepada pelaku pelanggaran. Konsep keadilan pemilu tidak hanya terbatas pada penegakan kerangka hukum, tetapi juga merupakan salah satu faktor yang perlu diperhatikan dalam merancang dan menjalankan seluruh proses pemilu. Keadilan pemilu juga merupakan faktor yang memengaruhi perilaku para pemangku kepentingan dalam proses tersebut. Karena sistem keadilan pemilu sangat dipengaruhi kondisi sosial-budaya, konteks sejarah dan politik masing-masing negara, maka sistem dan praktiknya di seluruh dunia berbeda-beda. ${ }^{2}$

Kehadiran sistem keadilan pemilu yang andal tidak dengan sendirinya menjamin pemilu yang bebas, adil, dan jujur, ketiadaan sebuah sistem dapat menyebabkan konflik yang ada semakin memburuk. Apabila pemilu diselenggarakan tanpa kerangka hukum yang komprehensif, tidak berdasarkan konsensus, tidak mengacu sepenuhnya pada prinsip dan nilai demokrasi, tidak diselenggarakan dengan baik, atau apabila tidak ada mekanisme keadilan pemilu khusus yang tersedia, proses

\footnotetext{
${ }^{1}$ Dalam Ilmu Negara Umum (algemeine staatslehre) yang dimaksud dengan sistem pemerintahan ialah sistem hukum ketatanegaraan, baik dalam negara berbentuk monarki maupun republik, yaitu mengenai hubungan antar pemerintah dan badan yang mewakili rakyat. Lihat Jimly Asshiddiqie, Pokok-Pokok Hukum Tata Negara Indonesia Pasca Reformasi. Buana Ilmu, Jakarta, 2007, hlm. 311.

${ }^{2}$ International IDEA Keadilan Pemilu diterjemahkan Bawaslu RI dan CETRO, Jakarta Indonesia Printer, Jakarta, Indonesia. Buku asli dicetak di Trydells Tryckeri AB, Swedia 2010. hlm 5.
} 
pemilu dapat memperburuk friksi yang sudah ada atau bahkan mengakibatkan terjadinya konflik bersenjata atau kekerasan. Sebagai contoh, salah satu kondisi yang mungkin menyebabkan terjadinya tindak kekerasan di Kenya menyusul berlangsungnya pemilu pada bulan Desember 2007 adalah ketiadaan pengadilan yang kredibel dan imparsial untuk menyelesaikan sengketa pemilu. ${ }^{3}$

Pemilihan umum calon anggota Dewan Perwakilan Rakyat, Dewan Perwakilan Rakyat Daerah Provinsi, dan Dewan Perwakilan Rakyat Daerah Kabupaten/ Kota dilaksanakan secara efektif dan efisien berdasarkan asas langsung, umum, bebas, rahasia, jujur, dan adil. Dalam menyelenggarakan pemilu, penyelenggara pemilu harus melaksanakan pemilu berdasarkan pada asas dan penyelenggaraannya harus memenuhi prinsip: ${ }^{4}$
a. Mandiri
b. Jujur
c. Adil
d. Berkepastian hukum
e. Tertib
f. Kepentingan umum
g. Terbuka
h. Proporsional
i. Profesional
j. Akuntabel
k. Efektif dan
1. Efisiensi.

Dalam sistem demokrasi langsung, setiap rakyat mewakili dirinya sendiri dalam memilih suatu kebijakan sehingga mereka memiliki pengaruh langsung terhadap keadaan politik yang terjadi. Sistem demokrasi langsung digunakan pada masa awal terbentuknya demokrasi di Athena di mana ketika terdapat suatu permasalahan yang harus diselesaikan, seluruh rakyat berkumpul untuk membahasnya. Sedangkan dalam demokrasi perwakilan, rakyat memilih perwakilan melalui pemilihan umum. Perwakilan-perwakilan yang terpilih tersebutlah yang selanjutnya menjadi representasi rakyat untuk menyampaikan pendapat dan mengambil keputusan bagi mereka. $^{5}$

Daftar calon sementara anggota Dewan Perwakilan Rakyat, daftar calon sementara anggota Dewan Perwakilan Rakyat Daerah Provinsi dan daftar calon sementara anggota Dewan Perwakilan Rakyat Daerah Kabupaten/ Kota yang selanjutnya disebut DCS anggota Dewan Perwakilan Rakyat, DCS anggota Dewan Perwakilan Rakyat Daerah Provinsi dan DCS anggota Dewan Perwakilan Rakyat

3 Ibid. hlm 7.

${ }^{4}$ Undang-Undang Republik Indonesia Nomor 7 Tahun 2017 Tentang Pemilihan Umum. Pasal 3

5 Mohammad, Saihu. Et al, Penyelenggara Pemilu di Dunia, Jakarta: Badan Penerbit Dewan Kehormatan Penyelenggara Pemili Republik Indonesia, 2015. hlm 12. 
Daerah Kabupaten/ Kota adalah daftar calon sementara yang memuat nomor urut Partai Politik, nama Partai Politik, tanda gambar Partai Politik, nomor urut calon, pas foto calon, nama lengkap, jenis kelamin dan Kabupaten/Kota atau Kecamatan tempat tinggal calon. Daftar calon tetap anggota Dewan Perwakilan Rakyat, daftar calon tetap anggota Dewan Perwakilan Rakyat Daerah Provinsi dan daftar calon tetap anggota Dewan Perwakilan Rakyat Daerah Kabupaten/ Kota yang selanjutnya disebut DCT anggota Dewan Perwakilan Rakyat, DCT anggota Dewan Perwakilan Rakyat Daerah Provinsi dan DCT anggota Dewan Perwakilan Rakyat Daerah Kabupaten/ Kota adalah daftar calon tetap yang memuat nomor urut Partai Politik, nama Partai Politik, tanda gambar Partai Politik, nomor urut calon, pas foto calon, nama lengkap calon, jenis kelamin dan Kabupaten/ Kota atau Kecamatan tempat tinggal calon. ${ }^{6}$

Komisi Pemilihan Umum Republik Indonesia telah mengeluarkan Peraturan Komisi Pemilihan Umum Nomor 20 Tahun 2018 tentang Pencalonan Anggota Dewan Perwakilan Rakyat, Dewan Perwakilan Rakyat Daerah Provinsi dan Dewan Perwakilan Rakyat Daerah Kabupaten/ Kota. Dalam persyaratan bakal calon anggota Dewan Perwakilan Rakyat, Dewan Perwakilan Rakyat Daerah Provinsi, dan Dewan Perwakilan Rakyat Daerah Kabupaten/ Kota pada Pasal 7 ayat 1 huruf 1 harus mengundurkan diri sebagai kepala desa dan perangkat desa yang mencakup unsur staf yang membantu kepala desa dalam penyusunan kebijakan dan koordinasi yang diwadahi dalam sekretariat desa, dan unsur pendukung tugas kepala desa dalam pelaksanaan kebijakan yang diwadahi dalam bentuk pelaksana teknis dan unsur kewilayahan atau badan lain yang anggarannya bersumber dari keuangan negara harus mengundurkan diri. ${ }^{7}$

Para kepala desa yang tergabung dalam Asosiasi Pemerintah Desa Seluruh Indonesia (Apdesi) merasa dihambat dengan adanya Peraturan Komisi Pemilihan Umum Nomor 20 Tahun 2018 tentang Pencalonan Anggota Dewan Perwakilan Rakyat, Dewan Perwakilan Rakyat Daerah Provinsi dan Dewan Perwakilan Rakyat Daerah Kabupaten/ Kota yang melarang kepada desa maju sebagai calon anggota dewan perwakilan rakyat. Sebab menjelang pemilihan legislatif 2019 mendatang tidak sedikit kepala desa yang berkeinginan ikut dalam pertarungan menjadi wakil rakyat. Oleh karena itu Apdesi menjelaskan, kepala desa dan perangkat desa merasa bahwa hak-hak mereka terhambat dengan adanya Peraturan Komisi Pemilihan Umum Nomor 20 tentang Pencalonan anggota Dewan Perwakilan Rakyat, Dewan Perwakilan Rakyat Daerah Provinsi dan Dewan Perwakilan Rakyat Daerah Kabupaten/ Kota tahun 2018, karena mereka harus mengundurkan diri dari jabatan

\footnotetext{
${ }^{6}$ Peraturan Komisi Pemilihan Umum Nomor 20 Tahun 2018 tentang Pencalonan Anggota Dewan Perwakilan rakyat, Dewan Perwakilan Rakyat Daerah Provinsi dan Dewan Perwakilan Rakyat Daerah Kabupaten/ Kota. Pasal 21.

7 Ibid. Pasal 7
}

Suloh: Jurnal Fakultas Hukum Universitas Malikussaleh, Vol. 9, No. 1, April 2021, pp. 70 - 88 
kepala desa, padahal di dalam Undang-Undang Nomor 7 tahun 2017 tentang Pemilihan Umum tidak disebutkan tentang kepala desa harus mengundurkan diri. ${ }^{8}$

Berdasarkan uraian di atas, maka permasalahan tentang syarat menjadi anggota legislatif bagi kepala desa menarik untuk dilakukan penelitian karena mengingat di dalam Undang-Undang Nomor 7 Tahun 2017 tentang Pemilihan Umum tidak disebutkan tentang kepala desa harus mengundurkan diri dan masih banyak dengan pekerjaan lainnya yang anggarannya bersumber dari keuangan negara tidak harus mengundurkan diri dalam pencalonan anggota legislatif pemilihan umum tahun 2019 sehingga beranjak dari hal tersebut penulis ingin meneliti lebih mendalam yang penulis tuangkan dalam penelitian tesis dibawah judul "Analisis Prinsip Keadilan Tentang Syarat Menjadi Anggota Legislatif Bagi Kepala Desa Berdasarkan Undang Undang Nomor 7 Tahun 2017 dan Peraturan Komisi Pemilihan Umum Nomor 20 Tahun 2018".

\section{Tujuan dan Kegunaan Penelitian}

Penelitian menuju kepada suatu tujuan dan kegunaan, dimana untuk mengungkap beberapa informasi penting dari hasil kajian sekaligus menyelesaikan beban studi. Oleh karena itu berpijak dari rumusan tersebut, maka yang menjadi tujuan dan kegunaan penelitian adalah sebagai berikut :

1. Untuk menjelaskan dan menganalisis prinsip keadilan dalam syarat menjadi anggota legislatif bagi kepala desa berdasarkan Undang-Undang Nomor 7 Tahun 2017 dan Peraturan Komisi Pemilihan Umum Nomor 20 Tahun 2018.

2. Untuk menjelaskan implikasi hukum terhadap syarat menjadi anggota legislatif bagi kepala desa berdasarkan Undang-Undang Nomor 7 Tahun 2017 dan Peraturan Komisi Pemilihan Umum Nomor 20 Tahun 2018.

\section{Keaslian Penelitian}

Untuk mengetahui keaslian penelitian ini, penulis telah melakukan penelusuran terhadap berbagai referensi baik melalui media cetak maupun media elektronik. Muhammad Aziz Hakim "Politik Hukum Sistem Pemilihan Umum di Indonesia pada Era Reformasi” Tesis Magister Hukum Universitas Indonesia pada tahun 2012, ${ }^{9}$ yang fokus penelitian membahas tentang pembentukan peraturan perundang-undangan yang terkait dengan pemilihan umum serta proses hasil pembentukan undang-undang.

Selain itu, Zaini "Penegakan Hukum pada Pelaksanaan Pemungutan dan Penghitungan Suara Pemilu anggota DPR, DPD, dan DPRD tahun 2014 di Kabupaten

\footnotetext{
8 Apdesi (Asosiasi Pemerintah Desa Seluruh Indonesia) https://www.kabar-banten. com/ apdesi-gugat-aturanyang-jegal- kepala-desa- untuk-jadi- anggota-dprd/ di lihat tanggal 28/12/2019.

${ }_{9}$ Politik Hukum Sistem Pemilihan Umum di Indonesia pada Era Reformasi Tesis Universitas Indonesia pada tahun 2012. file:///C:/Users/ LENOVO/AppData/Local/ Temp/digital_ 20283450-T29436-Politik\%20hukum2.pdf. 11 Desember 2019.
} 
Pemekasan" Tesis Magister Hukum Universitas Narotama Surabaya tahun 2015. ${ }^{10}$ Fokus penelitian membahas tentang kewenangan Panwaslu untuk menindak lanjuti pelanggaran yang dilakukan oleh penyelenggara pemilu, peserta pemilu maupun warga negara yang memiliki hak pilih.

Dengan demikian, Tohap Hasugian "Strategi Komisi Pemilihan Umum dalam meningkatkan partisipasi pemilih (Studi pada pemilih pemula, perempuan dan kelompok marjinal pada pemilihan Bupati dan Wakil Bupati 2018 di Kabupaten Dairi Provinsi Sumatera Utara)" Tesis Magister Ilmu Pemerintahan Fakultas Ilmu Sosial dan Politik Universitas Lampung Bandar Lampung tahun 2019. ${ }^{11}$ Penelitian ini berfokus pada strategi penyelenggra terhadap pengguna hak pilih bagi pemilih pemula, pemilih perempuan dan pemilih kelompok marjinal.

Penulisan tesis yang di angkat oleh penulis berbeda dengan penulisan tesis di atas, perbedaannya terletak kepala desa yang mencalonkan diri sebagai anggota legislatif. Dapat penulis simpulkan yang bahwa belum ada penulisan tesis yang sama dengan judul tesis penulis angkat dengan judul "Analisis Prinsip Keadilan Tentang Syarat Menjadi Anggota Legislatif Bagi Kepala Desa Berdasarkan Undang - Undang Nomor 7 Tahun 2017 dan Peraturan Komisi Pemilihan Umum Nomor 20 Tahun 2018". Dengan demikian penelitian ini dapat dikatakan memenuhi kaidah keaslian penelitian.

Adapun yang menjadi keaslian dalam penelitian ini diharapkan dapat memberikan sumbangan pemikiran bagi pengembangan ilmu pengetahuan khususnya tentang Pemilihan Umum dan hasil penelitian ini diharapkan memberikan sumbangan pemikiran yang dapat dipergunakan oleh penyusun/ revisi Peraturan Komisi Pemilihan Pemilihan Umum tentang Pencalonan Anggota Dewan Perwakilan Rakyat.

\section{Kerangka Teori dan Konseptual}

\section{Kerangka Teori}

Kerangka teori merupakan suatu kerangka awal untuk membangun suatu ide atau merupakan penjelasan dari permasalahan yang di analisis. Dengan demikian suatu teori adalah upaya menberikan penjelasan dengan cara mengorganisasikan dan mensistematikan seluruh masalah yang sedang dan akan dibahas. Menurut M.Solly Lubis kerangka teori adalah merupakan suatu pikiran atau butir-butir pendapat, teori, tesis mengenai suatu kasus atau permasalahan yang dapat menjadi bahan perbandingan dan pegangan teoritis. ${ }^{12}$

\footnotetext{
${ }^{10}$ Penegakan Hukum pada Pelaksanaan Pemungutan dan Penghitungan Suara Pemilu anggota DPR, DPD, dan DPRD tahun 2014 di Kabupaten Pemekasan Tesis Universitas Narotama Surabaya tahun 2015.http://repository.narotama.ac.id/214/2/tesis \%20 zaini .pdf. 11 desember 2019.

11 Strategi Komisi Pemilihan Umum Dalam Meningkatkan Partisipasi Pemilih Studi Pada Pemilih Pemula, Perempuan dan Kelompok Marjinal pada Pemilihan Bupati dan Wakil Bupati 2018 di Kabupaten Dairi Provinsi Sumatera Utara Tesis Universitas Lampung tahun 2019. http:// digilib. unila.ac.id/56237/3/tesis\%20tanpa\%20bab\%20pembahasan.pdf. 26 Desember 2019

${ }^{12}$ Lubis, M.Solly, Filsafat Hukum dan Penelitian, (Bandung, Mandar Maju, 1994), hlm 86
} 


\section{Kerangka Konseptual}

Dalam rangka menghindari pemahaman ganda tentang judul penelitian ini, maka penulis menggunakan definisi dan kerangka konseptual sebagai berikut :

a. Pemilihan umum yang selanjutnya disebut pemilu adalah sarana kedaulatan rakyat untuk memilih anggota Dewan Perwakilan Rakyat, anggota Dewan Perwakilan Daerah, Presiden dan Wakil Presiden, dan untuk memilih anggota Dewan Perwakilan Rakyat Daerah, yang dilaksanakan siara langsung, umum, bebas, rahasia, judur, dan adil dalam Negara Kesatuan Republik Indonesia berdasarkan Pancasila dan Undang-Undang Dasar Negara Republik Indonesia Tahun $1945 .^{13}$

b. Dewan Perwakilan Rakyat Daerah yang selanjutnya disingkat DPRD adalah Dewan Perwakilan Rakyat Daerah Provinsi dan Dewan Perwakilan Rakyat Daerah Kabupaten/ Kota sebaimana dimaksud dalam Undang-Undang Dasar Negara Republik Indonesia Tahun $1945 .^{14}$

c. Pemerintah desa adalah kepala desa atau yang disebut dengan nama lain dibantu perangkat desa sebagai unsur penyelenggara pemerintahan desa. ${ }^{15}$

\section{A. Analisis Prinsip Keadilan Calon Anggota Legislatif Bagi Kepala Desa}

Keadilan dan demokrasi dalam pemilu merupakan dua konsep yang saling berkaitan. Semua sistem demokrasi didukung melalui penyelenggaraan pemilihan yang berkala sementara pemilihan umum tidak bisa berhasil dalam sistem politik selain demokrasi. Tantangan demokrasi juga diperlukan pemahaman yang mendalam tentang reformasi pemilihan, membangun institusi demokrasi dan penguatan pada demokrasi substantif tidak hanya prosedural. ${ }^{16}$ Oleh karena itu ketidakpuasan warga negara terhadap proses demokrasi dan keadilan tersebut akan memberikan ancaman bagi stabilitas dan legistimasi sistem politik yang adil dan demokratis. ${ }^{17}$

Keadilan pemilu yang dirumuskan IDEA, Ramlan Surbakti sekalipun tidak memberikan definisi keadilan pemilu secara tegas, namun ia mengemukakan ada tujuh kriteria yang mesti dipenuhi untuk mewujudkan pemilu yang adil dan berintegritas. Tujuh kriteria tersebut adalah: ${ }^{18}$

\footnotetext{
${ }^{13}$ Undang-Undang Republik Indonesia Nomor 7 Tahun 2017 Tentang Pemilihan Umum

14 Ibid. Pasal. 1

${ }^{15}$ Undang-Undang Republik Indonesia Nomor 6 tahun 2014 tentang Desa.

${ }^{16}$ Harahap, H. Evaluasi Pelaksanaan Pilkada Serentak. 2016. Hlm. 17-23. Dalam Naskah Publikasi. Riska, Sarofah dan Titin. Purwaningsih.

17 Donovan, T., \& Karp, J. 2017. Electoral Rules, Corruption, Inequality and Evaluations of Democracy. European Journal of Political Research 2017. hlm 469-486. Dalam Naskah Publikasi. Riska, Sarofah dan Titin. Purwaningsih.

18 Ramlan Surbakti, Pemilu Berintegritas dan AdilFahmi. Dalam Jurnal Khairul, Menelusuri Konsep Keadilan Pemilihan Umum, Menurut Undang-Undang Dasar Negara Republik Indonesia Tahun 1945. 2016. 4 Jurnal Cita Hukum.
} 
1. Kesetaraan antarwarga negara, baik dalam pencalonan dan syarat calon maupun dalam alokasi kursi Dewan Perwakilan Rakyat dan Dewan Perwakilan Rakyat Daerah, pemungutan, penghitungan suara dan pembentukan daerah pemilihan.

2. Kepastian hukum yang dirumuskan berdasarkan asas pemilu demokratis

3. Persaingan bebas dan adil antar kontestan pemilu.

4. Partisipasi seluruh pemangku kepentingan dalam seluruh rangkaian penyelenggaraan tahap pemilu.

5. Badan penyelenggara pemilu yang profesional, independen, dan imparsial.

6. Integritas pemungutan, penghitungan, tabulasi, dan pelaporan suara pemilu.

7. Penyelesaian sengketa pemilu yang adil dan tepat waktu.

Apabila dilihat dari sisi keadilan asali, maka semua orang khususn ya masyarakat Indonesia yang sudah memenuhi syarat untuk hak dipilih dalam UndangUndang Nomor 7 Tahun 2017 tentang Pemilihan Umum dalam tataran persamaan hak, berhak untuk dipilih, kecuali dipersyaratkan lain oleh Undang-Undang khusus tentang pemilu. Sehingga berdasarkan prinsip keadilan asali, maka calon legislatif bagi kepala Desa bisa mencalonkan dirinya sebagai anggota legislatif dan memiliki hak untuk dipilih oleh masyarakat. Hal ini juga ditegaskan dalam Undang-Undang Nomor 7 Tahun 2017 tentang Pemilihan Umum, yaitu Pasal 240 dan Pasal 243. Berdasarkan Pasal 240 Undang-Undang Nomor 7 Tahun 2017 tentang Pemilihan Umum, tidak diatur mengenai kepala Desa harus mengundurkan diri dari kepala Desa sebagai salah satu syarat calon legislatif. Sehingga berdasarkan norma tersebut, tidak ada norma atau aturan mengenai larangan mencalonkan diri bagi kepala desa yang tidak mengundurkan diri. Sedangkan berdasarkan Pasal 243 Undang-Undang Nomor 7 Tahun 2017 tentang Pemilihan Umum calon legislatif adalah kewenangan dari Partai Politik peserta pemilu untuk menentukan mana yang layak menjadi calon anggota di Dewan Perwakilan, bagian dari tugas partai untuk melakukan seleksi berdasar aturan partainya sendiri, sehingga tidak ada halangan atau kewajiban untuk melarang bagi kepala Desa dan mencalonkan diri sebagai anggota legislatif. Sedangkan apabila ditinjau dari teori kedilan distributive, bahwa distribusi seseorang juga harus diutamakan nilai-nilai keadilannya. ${ }^{19}$

Sebelum Partai Politik mengumumkan calon-calonnya, pasti Partai Politik juga telah melihat, meneliti dan mendengar sepak terjang perbuatan-perbuatan yang dilakukan calon legislatif yang akan didaftarkan ke Komisi Pemilihan Umum. Dan Partai Politik tidak mungkin memilih calon legislatif yang akan diusungnya, apabila calon legislatif tersebut belum pernah memberikan distribusi kepada masyarakat dan tidak dikenal oleh msyarakat. Dengan demikian, untuk terjaminnya efektivitas dari kedua prinsip keadilan itu, Rawls menegaskan bahwa keduanya harus diatur dalam suatu tatanan yang disebutnya serial order atau lexical order. Sehingga dalam mengkaji terhadap calon legislatif bagi kepala Desa, harus dilihat dulu dari segi

${ }^{19}$ Undang - Undang Negara Republik Indonesia Nomor 7 Tahun 2017 tentang Pemilihan Umum. 
persamaan hak-hak asasi dan keadilan, sehingga dengan di keluarkannya Peraturan Komisi Pemilihan Umum Nomor 20 tentang Pencalonan anggota Dewan Perwakilan Rakyat, Dewan Perwakilan Rakyat Daerah Provinsi dan Dewan Perwakilan Rakyat Daerah Kabupaten/ Kota tahun 2018, pasal 7 huruf k poin 2 dan pasal 8 huruf b poin 6 , ini tidak terhalangi hak-hak kebebasan dan keadilan bagi kepala Desa dalam pencalonan sebagai anggota legislatif, Rawls menegaskan bahwa hak-hak serta kebebasan-kebebasan dasar tidak bisa ditukar dengan keuntungan-keuntungan sosial dan ekonomi (distributive). ${ }^{20}$

Hal ini berarti bahwa prinsip keadilan kedua hanya bisa mendapat tempat dan diterapkan apabila prinsip keadilan pertama telah terpenuhi. Dengan kata lain, penerapan dan pelaksanaan prinsip keadilan yang kedua tidak boleh bertentangan dengan prinsip keadilan yang pertama. Oleh karena itu hak-hak dan kebebasankebebasan dasar dalam konsep keadilan khusus ini memiliki prioritas utama atas keuntungan sosial dan ekonomi, khususnya terhadap calon legislatif yang masih menjabat sebagai kepala Desa.

Dalam konteks ini, keadilan pemilu tidak hanya terhenti pada bagaimana menciptakan sebuah aturan main yang adil dan berkepastian hukum, melainkan juga dapat dijadikan sebagai alat untuk menjaga suara rakyat. Keadilan pemilu tidak hanya terhenti pada tersedianya mekanisme penyelesaian sengketa dalam berbagai bentuknya, melainkan juga mampu memastikan bahwa semua warga negara terjamin hak-haknya dalam pembuatan aturannnya. Keadilan pemilu juga sampai pada level bagaimana institusi penyelenggara pemilu diisi oleh orang-orang nonpartisan serta mampu bekerja dengan integritas yang terjaga. Bahkan, keadilan pemilu juga menjangkau titik yang paling rumit, di mana rakyat sebagai tumpuan demokrasi memiliki pemahaman yang cukup akan keberadaannya sebagai penentu proses peralihan kekuasaan melalui pemilu yang berjalan secara fair. Dengan demikian, keadilan pemilu mencakup semua aspek yang mempengaruhi bagaimana pemilu sebagai sebuah kontestasi berjalan secara bebas dan setara dalam pencalonan anggota legislatif. $^{21}$

\section{B. Analisis Syarat Calon Anggota Legislatif Pada Pemilihan Umum Bagi Kepala Desa}

Berdasarkan pengalaman pelaksanaan pemilu di seluruh dunia bahwa terdapat beberapa masalah seperti pelanggaran pada saat menyusun Peraturan Komisi Pemilihan Umum, Pencalonan anggota Dewan Perwakilan Rakyat, pemungutan suara, dan kekerasan yang banyak ditemukan di seluruh dunia, sehingga perlu membuat konteks standar Internasional yang harus dipenuhi oleh penyelenggara

\footnotetext{
20 Ibid. Pasal 7

${ }^{21}$ Fahmi. Khairul, Menelusuri Konsep Keadilan Pemilihan Umum, Menurut Undang-Undang Dasar Negara Republik Indonesia Tahun 1945. 2016. 4 Jurnal Cita Hukum.
} 
pelaksanaan pemilu. Indeks evaluasi telah dikembangkan untuk membandingkan kualitas pemilihan umum di beberapa provinsi atau daerah pemilihan dalam sebuah negara. $^{22}$

Siklus Pemilu merupakan salah satu instrumen yang menjamin bahwa pelaksanaan Pemilu secara berkeadilan merupakan kegiatan yang berlangsung secara terus-menerus dan berlanjut. Secara umum bahwa siklus pemilu terbagi atas 3 periode, antara lain pra pemilihan (pre-electoral period), periode pelaksanaan pemilu (electoral period), pasca pemilu (post electoral period). Sejumlah tahapan penyelenggara pemilu yang berlaku universal, yaitu: ${ }^{23}$

1. Pembuatan landasan hukum pemilu (legal framework)

2. Perencanaan dan pembuatan kebijakan anggaran untuk mendukung logistik pemilu (planning and implementation).

3. Perekrutan, pelatihan, pendidikan, dan penyebaran informasi pemilu (training, education, and election socialization).

4. Pendataan dan pendaftaran pemilih (voter registration)

5. Perencanaan dan pelaksanaan kampanye pemilu (electoral campaign)

6. Pemungutan suara (election day and counting)

7. Pengesahan hasil (veryfication of result)

8. Tahapan setelah pemilu (post election

Berdasarkan dari hasil catatan proses dan hasil pembahasan proses pembuatan Undang-Undang Pemilihan Umum diatas tidak ada subtansi pembahasan khusus menyangkut dengan syarat calon bagi Kepala Desa yang harus mengundurkan diri pada saat mau ditetapkan sebagai daftar calon tetap (DCT) oleh Komisi Pemilihan Umum seperti pada pasal 240 Undang-Undang Nomor 7 Tahun 2017 tentang Pemilihan Umum. ${ }^{24}$ Standar Internasional untuk menghasilkan pemilu yang demokratis adalah syarat mutlak dalam kerangka hukum yang harus diimplementasikan dalam pelaksanaan pemilu. Standar ini bersumber pada berbagai deklarasi dan konvensi Internasional maupun regional, seperti Deklarasi Universal Hak Asasi Manusia 1984, perjanjian Internasional tentang Hak-Hak Sipil dan Politik 1960, konvensi Eropa 1950 untuk perlindungan Hak Asasi Manusia dan kebebasan asasi serta piagam Afrika 1981 tentang Haka Asasi Manusia dan masyarakat. ${ }^{25}$

Kelayakan syarat-syarat formal bisa diturunkan dari prinsip hak dalam menyusuaikan klaim-klaim yang dibuat orang-orang pada institusi-institusi mereka. Jika prinsip-prinsip keadilan ingin memainkan peranan, yakni peranan untuk

22 James, T. S. (n.d). Building Better Elections: The Role of Human Resource Management Practices, 2017. 1-21. Analisis Tata Kelola Pemilukada dalam Perspektif Electoral Integritydi Kota Yogyakarta Tahun 2017. (dalam Naskah Publikasi. Riska, Sarofah dan Titin. Purwaningsih).

${ }^{23}$ Ibid

${ }^{24}$ Undang-Undang Negara Republik Indonesia Nomor 7 Tahun 2017 tentang Pemilihan Umum.

${ }^{25}$ Perdana, Aditya Op. Cit. hlm 289

Suloh: Jurnal Fakultas Hukum Universitas Malikussaleh, Vol. 9, No. 1, April 2021, pp. 76 - 88 
memberikan hak-hak dan kewajiban dasar serta menetukan pembagian keuntungan, keharusan-keharusan tersebut cukup alamiah. Masing-masing lemah dan saya anggap mereka dipenuhi oleh konsepsi tradisional tentang keadilan. Syarat-syarat tersebut bagaimanapun menyingkirkan berbagai bentuk egoisme, menunjukkan bahwa mereka bukan tanpa kekuatan moral. Hal ini semakin menunjukkan bahwa berbagai syarat tidak dijustifikasi oleh definisi atau analisis konsep, namun hanya oleh rasionalitas teori yang melengkapinya. ${ }^{26}$

\section{Analisis Prinsip Keadilan Syarat Calon Anggota Legislatif pada Pemilihan Umum bagi Kepala Desa}

Setiap tahapan Pemilu perlu dicermati, terutama menyangkut potensi permasalahan hukum. Permasalahan hukum yang tidak tuntas di satu tahapan akan mengganggu pelaksanaan tahapan berikutnya. Tahapan pencalonan memiliki arti penting karena dari calon-calon ini nantinya akan ditetapkan calon terpilih. Apabila masih menyisakan permasalahan hukum calon terpilih, legitimasi Pemilu akan dipertanyakan. Tulisan ini ingin menggambarkan peta permasalahan hukum dalam tahap pencalonan Pemilu 2019 dan mengkaji upaya yang perlu dilakukan untuk mengatasi permasalahan tersebut.

Berdasarkan teori hukum, suatu norma tidak boleh bertentangan dengan norma yang ada di atasnya. Hal inilah yang dimaksud sebagai sistem hierarki norma hukum atau perundang-undangan. Hierarki dalam hal ini dapat dimaknai sebagai suatu tata tingkatan aturan hukum, atau struktur norma hukum tertulis dalam peraturan perundang-undangan. Oleh karena itu, idealnya suatu pembentukan peraturan seharusnya tidak boleh bertentangan dengan peraturan yang ada di atasnya. Karena peraturan yang ada di tingkatan atas mendasari pembentukan peraturan yang ada di bawahnya. Pembentukan peraturan seharusnya memperhatikan salah satu asas-asas peraturan perundangan yang menyebutkan bahwa peraturan perundang-undangan yang dibuat oleh penguasa yang memiliki kedudukan lebih tinggi mempunyai kedudukan yang tinggi pula atau lex superiori derogat legi inferiori. ${ }^{27}$

Jenis dan hierarki Peraturan Perundang-undangan di Indonesia diatur dalam ketentuan Pasal 7 ayat (1) Undang-undang Nomor 12 Tahun 2011 Tentang Pembentukan Peraturan Perundang-undangan, adalah sebagai berikut:

a. Undang-Undang Dasar Negara Republik Indonesia Tahun 1945

b. Ketetapan Majelis Permusyawaratan Rakyat

c. Undang-Undang/Peraturan Pemerintah Pengganti Undang-Undang

d. Peraturan Pemerintah

e. Peraturan Presiden

26 Rawls John. Op. Cit. hlm 158

27 Soerjono Soekanto dan Purnadi Purbacaraka. Perihal Kaidah Hukum. Bandung: PT. Citra Aditya Bakti, 1993. hlm 92

Suloh: Jurnal Fakultas Hukum Universitas Malikussaleh, Vol. 9, No. 1, April 2021, pp. 77 - 88 
f. Peraturan Daerah Provinsi dan

g. Peraturan Daerah Kabupaten/Kota

Peraturan Komisi Pemilihan Umum merupakan pelaksanaan dari peraturan perundang-undangan sebagaimana yang dimaksud dalam Pasal 75 ayat (1) dan ayat (2) Undang-Undang Nomor 7 Tahun 2017 tentang Pemilihan Umum yang mengatur bahwa untuk menyelenggarakan Pemilu sebagaimana diatur dalam Undang-Undang ini, Komisi Pemilihan Umum membentuk Peraturan Komisi Pemilihan Umum dan Keputusan Komisi Pemilihan Umum. Apabila terdapat suatu norma hukum atau peraturan yang lebih rendah tingkatannya dianggap atau dipandang bertentangan dengan peraturan yang lebih tinggi, maka Undang-Undang Nomor 12 Tahun 2011 memberikan solusi dengan dilakukannya mekanisme pengujian (uji materiil). Dalam konteks ini, jika terdapat Peraturan Komisi Pemilihan Umum yang dipandang bertentangan dengan asa keadilan dan Undang-Undang Pemilihan Umum, maka pengujiannya dilakukan di Mahkamah Agung sesuai dengan pengaturan dalam Pasal 9 ayat (2) Undang-Undang Nomor 12 Tahun 2011.

Syarat calon anggota legislatif berdasarkan berdasarkan Undang-Undang Nomor 7 Tahun 2017 tentang Pemilihan Umum pasal 240 tidak menyebutkan yang bahwa Kepala Desa harus mengundurkan diri, tetapi di dalam Peraturan Komisi Pemilihan Umum Nomor 20 tahun 2018 tentang Pencalonan anggota Dewan Perwakilan Rakyat, Dewan Perwakilan Rakyat Daerah Provinsi dan Dewan Perwakilan Rakyat Daerah Kabupaten/ Kota pada Pasal 8 ayat 1 huruf b angka 6 poin b Kepala Desa harus mengundurkan diri dan tidak dapat ditarik kembali walaupun calon legislatif dari Kepala Desa tidak terpilih. Sehingga prinsip asas keadilan mempunyai arti bahwa semua yang terlibat dalam Pemilihan Umum haruslah memiliki hak yang sama dalam pencalonan anggota legislatif. ${ }^{28}$

Peraturan Komisi Pemilihan Umum Nomor 20 Tahun 2018 memiliki kedudukan yang sama dengan Peraturan Komisi Pemilihan Umum pada umumnya dalam peraturan perundang-undangan di Indonesia, yaitu diakui keberadaannya dan mempunyai kekuatan hukum mengikat, karena diperintahkan oleh Peraturan Perundang - undangan yang lebih tinggi atau dibentuk berdasarkan kewenangan. Selain itu, Peraturan Komisi Pemilihan Umum Nomor 20 Tahun 2018 telah diundangkan dalam Berita Negara Republik Indonesia Tahun 2018 Nomor 834. Sifat mengikat tersebut berarti Peraturan Komisi Pemilihan Umum ini harus dipatuhi oleh setiap warga negara maupun institusi yang terkait dengan Peraturan Komisi Pemilihan Umum Nomor 20 Tahun 2018 termasuk bakal calon anggota Dewan Perwakilan Rakyat, Dewan Perwakilan Daerah dan Dewan Perwakilan Rakyat

${ }^{28}$ Undang-Undang Nomor 7 Tahun 2017 tentang Pemilihan Umum 
Daerah, seluruh Partai Politik Peserta Pemilu, Penyelenggara Pemilu (KPU, Bawaslu dan DKPP) serta stakeholder dan masyarakat umum.

\section{Implikasi Hukum Terhadap Syarat Calon Anggota Legislatif bagi Kepala Desa}

Secara umum, Pemilu tahun 2019 tidak lah jauh berbeda dengan sebelumnya yaitu terdiri dari tiga jenis pemilihan umum, Pemilu Dewan Perwakilan Rakyat dan Dewan Perwakilan Rakyat Daerah, Pemilu Dewan Perwakilan Daerah, dan Pemilu Presiden dan Wakil Presiden. Pemilu Dewan Perwakilan Rakyat dan Dewan Perwakilan Rakyat Daerah adalah sarana untuk memilih anggota perwakilan rakyat di tingkat nasional, Provinsi dan Kabupaten/Kota berdasarkan unsur keterwakilan Partai Politik yang terdaftar sebagai peserta Pemilu. Hal yang berbeda dengan Pemilu 2014 lalu adalah, penerapan ambang batas perolehan suara bagi Partai Politik yang berkompetisi dalam Pemilu Dewan Perwakilan Rakyat dinaikkan dari 3,5 persen menjadi 4 persen. Artinya hanya Partai Politik yang memperoleh minimal suara sebanyak 4 persen dapat dinyatakan secara sah mendapatkan kursi di Dewan Perwakilan Rakyat. ${ }^{29}$

Indonesia telah berulang kali menyelenggarakan pemilu yang disebut sebagai pesta demokrasi rakyat Indonesia. Pemilu merupakan salah satu perwujudan pelaksanaan demokrasi yang pada hakikatnya diselenggarakan sebagai sarana kedaulatan rakyat, dan sarana partisipasi masyarakat. Teori demokrasi konstitusional tidak dapat lepas dari konsep demokrasi dan nomokrasi, karena kedua konsep tersebut saling berkonvergensi sehingga memunculkan konsep negara hukum yang demokratis (democratische rechtsstaat) dan negara demokrasi berdasarkan hukum (constitutional democratic) atau yang disebut sebagai negara demokrasi konstitusional (constitutional democratic state). ${ }^{30}$

Pelaksanaan Pemilihan Umum Serentak tahun 2019 untuk menyongsong pelaksanaan pesta demokrasi rakyat tersebut, berbagai peraturan sudah diundangkan oleh pemerintah. Sebagai pihak yang diberi kewenangan oleh undang-undang untuk merumuskan aturan penyelenggaraan (electoral law) dan pelaksanaan Pemilihan Umum (electoral process), Komisi Pemilihan Umum mengeluarkan Peraturan Komisi Pemilihan Umum sebagai peraturan pelaksanaan tahapan penyelenggaraan Pemilihan Umum Tahun 2019. Komisi Pemilihan Umum mengeluarkan satu peraturan yang disebut PKPU. Peraturan Komisi Pemilihan Umum sebagai sebuah peraturan perundang-undangan yang jelas kedudukannya dalam hierarki peraturan perundang-undangan. Peraturan Komisi Pemilihan Umum diakui dan memiliki

\footnotetext{
29 Nur Imam Subono. Et. al. Pembekalan Calon Anggota Legislatif. Modul. Kementrian Pemberdayaan Perempuan dan Anak. Republik Indonesia. 2017. hlm 84

${ }^{30}$ Bisarida Et al. Komparasi Mekansime Penyelasaian Sengketa Pemilu di Beberapa Negara Penganut Paham Demokrasi. Jurnal Konstitusi, Vol. 9, Nomor 3, 2012, hlm.538
} 
kekuatan hukum mengikat, sehingga memiliki konsekuensi atau akibat bagi setiap masyarakat atau institusi yang terkait dengan Peraturan Komisi Pemilihan Umum.

Salah satu Peraturan Komisi Pemilihan Umum yang sempat kontroversial dan mendapat banyak sorotan masyarakat tentang persyaratan pendaftaran calon anggota legislatif tahun 2019. Aturan tersebut adalah Peraturan Komisi Pemilihan Umum Nomor 20 Tahun 2018 tentang Pencalonan Anggota Dewan Perwakilan Rakyat, Dewan Perwakilan Rakyat Daerah Provinsi, dan Dewan Perwakilan Rakyat Daerah Kabupaten/Kota. Terdapat hal yang menarik untuk dipahami dan dikaji dari Peraturan Komisi Pemilihan Umum Nomor 20 Tahun 2018 khususnya tentang syarat bakal calon anggota Dewan Perwakilan Rakyat, Dewan Perwakilan Rakyat Daerah Provinsi, dan Dewan Perwakilan Rakyat Daerah Kabupaten/Kota, Pasal 7 ayat (1) huruf k angka 2 Peraturan Komisi Pemilihan Umum Nomor 20 Tahun 2018 tersebut mengatur bahwa salah satu syarat sebagai bakal calon anggota Dewan Perwakilan Rakyat, Dewan Perwakilan Rakyat Daerah Provinsi, dan Dewan Perwakilan Rakyat Daerah Kabupaten/Kota adalah harus mengundurkan diri sebagai Kepala Desa dan tidak dapat ditarik kembali bagi calon yang tidak terpilih menjadi anggota legislatif.

Banyak pihak yang menyampaikan Peraturan Komisi Pemilihan Umum tersebut melanggar hak asasi manusia para calon legislatif khususnya hak Kepala Desa untuk mencalonkan diri. Hal ini dikuatkan dengan adanya Para Kepala Desa yang tergabung dalam Asosiasi Pemerintah Desa Seluruh Indonesia (Apdesi) menjelaskan, Kepala Desa dan perangkat desa merasa, bahwa hak-hak mereka terhambat dengan adanya Peraturan Komisi Pemilihan Umum. Peraturan perundang-undangan tidak dapat mencabut hak pilih (hak politik) seseorang, melainkan hanya memberi pembatasan sesuai Pasal 28J Undang-Undang Dasar Negara Republik Indonesia Tahun 1945. Oleh karena itu, Peraturan Komisi Pemilihan Umum Nomor 20 Tahun 2018 yang melarang bagi Kepala Desa untuk mencalonkan diri sebagai calon legislatif harus mengundurkan diri sebelum ditetapkan menjadi daftar calon tetap, artinya Peraturan Komisi Pemilihan Umum telah memberikan hukuman tambahan mencabut hak politiknya. Pencabutan hak politik seseorang hanya dapat dilakukan dengan putusan hakim sebagai hukuman tambahan.

Peraturan Komisi Pemilihan Umum Nomor 20 Tahun 2018 dapat dilihat dari sudut pandang substansi regulasi. Sebagian pihak ada yang menyatakan, bahwa Peraturan Komisi Pemilihan Umum tersebut bertentangan dengan perundangundangan diatasnya yaitu Undang-Undang Nomor 7 Tahun 2017 tentang Pemilihan Umum. Kedudukan hukum tentang syarat seorang warga negara untuk dapat mencalonkan diri sebagai bakal calon legislatif telah diatur sebelumnya dalam Undang-Undang Nomor 7 Tahun 2017 tentang Pemilihan Umum. Dalam Pasal 240, menyatakan bahwa bakal calon Dewan Perwakilan Rakyat, Dewan Perwakilan Rakyat Daerah Provinsi, dan Dewan Perwakilan Rakyat Daerah Kabupaten/Kota adalah Warga Negara Indonesia yang harus memenuhi persyaratan dan kelengkapan 
administrasi bakal calon, tidak menyebutkan bagi Kepala Desa yang harus mengundurkan diri.

Sebagaimana yang telah diatur dalam Pasal 257 Undang-Undang Nomor 7 Tahun 2017 tentang Pemillihan Umum, menyebutkan bahwa "Ketentuan lebih lanjut mengenai pedoman teknis pencalonan anggota Dewan Perwakilan Rakyat, Dewan Perwakilan Rakyat Daerah Provinsi, dan Dewan Perwakilan Rakyat Daerah Kabupaten/Kota diatur dalam Peraturan Komisi Pemilihan Umum”. Berdasarkan hal tersebut, Peraturan Komisi Pemilihan Umum sebagai suatu peraturan yang sifatnya mengatur lebih lanjut dan lebih teknis, sepatutnya pengaturannya tidak "melebihi batas" yang diberikan undang-undang, apalagi bertentangan secara norma hukum.

Berdasarkan berbagai argumentasi di atas, ada dua hal penting yang dapat disimpulkan mengenai Peraturan Komisi Pemilihan Umum Nomor 20 Tahun 2018. Pertama, yaitu bahwa Komisi Pemilihan Umum tidak melakukan abuse of power karena Komisi Pemilihan Umum hanya menjalankan tugas dan kewenangannya sebagai penyelenggara Pemilu yang memiliki kewenangan merumuskan aturan penyelenggaraan (electoral law) dan pelaksanaan Pemilu (electoral proces) yang independen karena sifatnya full authority yang tidak mendapat intervensi atau pengaruh dari lembaga lain. Kedua, menurut segi substansi berdasarkan asas pembentukan peraturan perundang-undangan, harus diakui bahwa Peraturan Komisi Pemilihan Umum ini tidak sesuai dengan asas pembentukan peraturan perundangundangan yaitu asas kesesuaian antara hierarki, jenis, materi dan muatan. Peraturan Komisi Pemilihan Umum dinilai bertentangan dengan Undang-Undang Nomor 7 Tahun 2017 tentang Pemilihan Umum, sehingga dapat dikatakan batal demi hukum, dengan konsekuensi tidak memiliki kekuatan hukum mengikat kepada siapapun.

Prinsip penyelenggaraan Pemilu salah satunya adalah berkepastian hukum, prinsip ini erat hubungannya dengan salah satu dari tujuan suatu hukum itu dibuat. Tujuan hukum ada tiga, yaitu kepastian, keadilan dan kemanfaatan, yang merupakan satu rangkaian yang saling berhubungan satu sama lain. Kepastian hukum merupakan manifestasi dari kewajiban imperatif para penyelenggara Pemilu dalam melaksanakan ketentuan yang ada di dalam perundang-undangan. Bersumber pada norma hukum, akan memberikan kepastian pada semua pihak yang terlibat dalam Pemilu, sehingga peserta Pemilu dan masyarakat mempunyai harapan terhadap penyelenggara Pemilu dapat menjaga kelangsungan demokrasi. ${ }^{31}$

Semua ketentuan yang mengatur tentang Pemilu harus konsisten satu sama lain, sehingga tidak terjadi kontradiksi antar ketentuan atau antar peraturan. Peraturan Komisi Pemilihan Umum yang disusun oleh Komisi Pemilihan Umum tidak berkontradiksi dengan Undang-Undang Pemilihan Umum, karena Peraturan Komisi Pemilihan Umum merupakan penjabaran dari pelaksanaan teknis Undang-Undang Pemilihan Umum, hal ini merupakan wujud Peraturan Komisi Pemilihan Umum

${ }^{31}$ Fajlurrahman, Jurdi. Pengantar Hukum Pemilihan Umum. Jakarta: Prenada Media, 2018, hlm. 71 
dapat memberikan kepastian hukum bagi pelaksanaan hukum Pemilu tahun 2019. Tidak hanya mengutamakan kepastian hukumnya saja, tetapi Komisi Pemilihan Umum dalam membahas Peraturan Komisi Pemilihan Umum dalam rapat dengar pendapat dengan DPR dan Pemerintah haruslah berkarakter responsif. Untuk menjadi responsif suatu produk hukum harus berorientasi pada tujuan hukum yaitu keadilan dan kemanfaatan bagi masyarakat.

\section{Kesimpulan}

Berdasarkan hasil penelitian ini maka disimpulkan sebagai berikut :

1. Pemilu adalah sarana pelaksanaan kedaulatan rakyat yang dilaksanakan secara langsung, umum bebas, rahasia, jujur dan adil dalam Negara Kesatuan Republik Indonesia berdasarkan Pancasila dan Undang-Undang Dasar Negara Republik Indonesia Tahun 1945. Pemilu yang di laksanakan pada tahun 2019 tidak melaksanakan prinsip-prinsi keadilan dalam syarat calon anggota legislatif bagi Kepala Desa berdasar Peraturan Komisi Pemilihan Umum Nomor 20 tahun 2018 pasal 8 ayat 1 huruf $b$ angka 6 poin $b$ Kepala Desa harus mengundurkan diri pada saat mendaftar.

2. Berdasarkan berdasarkan Undang-Undang Nomor 7 Tahun 2017 tentang Pemilihan Umum pasal 240 tidak menyebutkan syarat calon bagi Kepala Desa harus mengundurkan diri, tetapi di dalam Peraturan Komisi Pemilihan Umum Nomor 20 tahun harus mengundurkan diri. Peraturan Komisi Pemilihan Umum merupakan penjabaran dari pelaksanaan teknis Undang-Undang Pemilihan Umum, hal ini merupakan wujud Peraturan Komisi Pemilihan Umum dapat memberikan kepastian hukum bagi pelaksanaan hukum Pemilu tahun 2019. Tidak hanya mengutamakan kepastian hukumnya saja, tetapi untuk menjadi responsif suatu produk hukum harus berorientasi pada tujuan hukum yaitu keadilan dan kemanfaatan bagi masyarakat.

\section{Saran}

a. Kepada Komisi Pemilihan Umum untuk merevisi Peraturan Komisi Pemilihan Umum tentang pencalonan anggota DPR, DPRD Provinsi, dan DPRD Kabupaten/Kota khusus dalam syarat calon bagi Kepala Desa pada Pasal 8 ayat 1 huruf $b$ angka 6 poin $b$, untuk menjamin hak-hak warga Negara dan memenuhi prinsip-prinsip keadilan.

b. Untuk mewujudkan Pemilu yang adil dan berintegritas, memberikan kepastian hukum dan mencegah tumpang tindih peraturan dalam syarat calon anggota legislatif. Untuk meminimalisir lahir nya gugata pengujian oleh Para Kepala Desa yang tergabung dalam Asosiasi Pemerintah Desa Seluruh Indonesia 
(Apdesi) ke Mahkamah Agung Republik Indinesia terhadap Peraturan Komisi Pemilihan Umum Nomor 20 tahun 2018 pada syarat calon tentang Kepala Desa.

\section{Daftar Pustaka}

A. Buku

Amrizal, Dedi Et al. Penangulangan GOLPUT Dalam Pelaksanaan Pemilu Legislatif dan Pilkada. Lembaga Penelitian dan Penulisan Ilmiah Aqil: Medan. 2018.

Ardiles, R. M. Mewoh, Et al. Pemilu Dalam Perpektif Penyelenggara. Perkumpulan Untuk Pemilu dan Demokrasi. Cetakan Pertama. Jakarta. Mei 2015.

Asshiddiqie, Jimly, Gagasan Konstitusi Sosial, Institusionalisasi dan Konstitusionalisasi Kehidupan Sosial Masyarakat Madani. Yogjakarta, 2015, LP3ES.

------Pokok-Pokok Hukum Tata Negara Indonesia Pasca Reformasi. Buana Ilmu, Jakarta, 2007.

Asmoro, Achmadi, Filsafat Umum. Cet. V; Jakarta: PT Raja Grafindo Persada, 2003.

Budiardjo, Miriam, Demokrasi di Indonesia: Demokrasi Parlementer dan Demokrasi Pancasila. Jakarta.PT Gramedia Pustaka Utama. 1996

------Dasar-Dasar Ilmu Politik. Jakarta: Gramedia Pustaka Utama, 2008.

C. F. Strong. Konstitusi-Konstitusi Politik Modern: Kajian Tentang Sejarah dan Bentuk-Bentuk Konstitusi Dunia, diterjemahkan dari Modern Political Constitution: An Introduce to the Comparative Study of Their History and Existing Form, Bandung: Nuansa dengan Nusa Media, 2004.

Donovan, T., \& Karp, J. 2017. Electoral Rules, Corruption, Inequality and Evaluations of Democracy. European Journal of Political Research 2017. Analisis Tata Kelola Pemilukada dalam Perspektif Electoral Integritydi Kota Yogyakarta Tahun 2017. Dalam Naskah Publikasi. Riska, Sarofah dan Titin. Purwaningsih.

Eklit, J \& Reynolds, A. Framework for the Systematic Study of Election Quality. Democratization. 2005.

Fahruurodji, A, Rusia Baru Menuju Demokrasi, Pengantar Sejarah dan Latar Belakang Budayanya; edisi:1. Jakarta, Yayasan Obor Indonesia, 2005.

Firmanzah. Persaingan Legitimasi Kekuasaan, Dan Marketing Politik Pembelajaran Politik Pemilu 2009. Edisi Ke-1, Yayasan Pustaka Obor Indonesia Anggota IKAPI DKI Jakarta, Jakarta, 2010.

Harahap, H. Evaluasi Pelaksanaan Pilkada Serentak. 2016. Analisis Tata Kelola Pemilukada dalam Perspektif Electoral Integritydi Kota Yogyakarta Tahun 2017. Dalam Naskah Publikasi. Riska, Sarofah dan Titin. Purwaningsih.

Hidayat, Sardini, Nur. Restorasi Penyelenggara Pemilu di Indonesia. Jakarta: Fajar Media Press, 2012. 
Ibrahim Johnny. Teori \& Metodologi Penelitian Hukum Normatif. Cet 3. Malang : Bayumedia Publishing, 2007.

Idris. Pendidikan Pembelajaran dan Penyebaran Kewarganegaraan. Malang: Fakultas Peternakan Universitas Brawijaya. 2005.

International IDEA Keadilan Pemilu, International Institute for Democracy and Electoral Assistance. Diterjemahkan Bawaslu RI dan Centro, Jakarta Indonesia Printer, Jakarta, Indonesia. Buku asli dicetak di Trydells Tryckeri ab, Swedia 2010.

Janedjri, M. Gaffar, Demokrasi dan Pemilu di Indonesia, Konpress, Jakarta, 2013.

Jurdil Fajlurrahman. Pengantar Hukum Pemilihan Umum. Kencana: Jakarta. 2018.

------Mekanisme Penyelesaian Pelanggaran Kode Etik Penyelenggara Pemilu. Jakarta: LP2AB, 2015.

Kansil. C.S.T. Dasar-dasar Ilmu Politik. Yogyakarta: UNY Press. 1986.

Kelsen, Hans, Introduction to The Problems of Legal Theory, translated by Bonnie Litschewski Paulson and Stanley L. Paulson, Oxford : Clarendon Press, 1992.

Leback Karen, Six Theories of Justice. Teori-Teori Keadilan: Analisis Kritis Terhadap Pemikiran J.S. Mill. John Rawls, Robert Nozick, Reinhold Neibuhr, Jose Porfirio Miranda.

Leback Karen, Six Theories of Justice. Teori-Teori Keadilan: Analisis Kritis Terhadap Pemikiran J.S. Mill. John Rawls, Robert Nozick, Reinhold Neibuhr, Jose Porfirio Miranda.

Leo Wiratma I Made, Et al. Panduan Lengkap Pemilu 2019. FORMAPPI: Jakarta. 2018.

Losco, Joseph dan Leonard Williams, Political Theory, Kajian Klasik dan Kontempoter Pemikiran Machiavelli-Rawls, Volume II, Jakarta : PT. RajaGrafindo Persada, 2005.

Lubis, M.Solly, Filsafat Hukum dan Penelitian, Bandung, Mandar Maju, 1994

Marzuki, Peter Mahmud, Penelitian Hukum. Cet 6. Jakarta : Kencana, 2010.

Mashudi, Pengertian-Pengerlian Alendasar Kedudukan Hukum Pemilihan Umum di Indonesia. Metrul Undang-Undang Dasar Tahun 1945, Mandar Maju, Bandung, 1993.

Mozaffar, S. \& Schedler, A. The Comparative Study of Electoral GovernanceIntroduction. International Political Science Review. 2002.

Nurhasim. Moch, Fisibilitas Sistem Pemilu Campuran: Upaya Memperkuat Sistem Presidensial Di Indonesia. Lembaga Ilmu Pengetahuan Indonesia. 2014.

Perdana, Aditya, Et al. Tata Kelola Pemilu di Indonesia. Cetak Pertam. Komisi Pemilihan Umum Repiblik Indonesia. Jakarta Pusat. 2019.

Prasetyo, Teguh. Filsafat Pemilu. Penerbit Nusa Media PO Box 137 Ujungberung, Bandung Bekerjasama Dewan Kehormatan Penyelenggara Pemilu. DKPP Republik Indoensia. November 2018. 
Rawls John, Teori Keadilan, Dasar-Dasar Filsafat Politik Untuk Mewujudkan Kesejahtraan Sosial Dalam Negara, Harvard University Press. Cambridge, Massachusetts, 1995. Penerbit Pustaka Pelajar Yogjakarta. 2006.

Rahardjo Satjipto, Penegakan Hukum Suatu Tinjauan Sosiologis. Yogyakarta; Genta Publishing, 2009.

Ramadhanil, Et al, Desain Partisipasi Masyarakat Dalam Pemantauan Pemilu. Handbook Kemitraan Pembaharuan Tata Pemerintahan di Indonesia. 2015.

Rauf, Maswadi, Demokrasi dan Demokratisasi, Penjajakan Teoritis untuk Indonesia, dalam Seri Penerbitan Studi Politik, Bandung: Fakultas Ilmu Sosial dan Ilmu Politik Universitas Indonesia. 1998.

Rizal, Mustansyir dan Misnal Munir, Filsafat Ilmu. Cet. VII Yogyakarta: Pustaka Pelajar, 2008.

Rosyada, Dede Et al, Memilih dan Dipilih. Jakarta: P.T. Pradnya Paramita, cetakan ketiga yang disederhanakan. 2005.

Santoso, Topo dan Supriyanto Didik, Mengawasi Pemilu, Mengawal Demokrasi, Murai Kencana, Jakarta, 2004.

Sardini, Hidayat, Nur. Restorasi Penyelenggaraan Pemilu di Indonesia. Fajar Media Press. Yogyakarta. 2011.

Saihu, Mohammad, Et al. Penyelenggara Pemilu di Dunia, Jakarta: Badan Penerbit Dewan Kehormatan Penyelenggara Pemilu Republik Indonesia, 2015.

Serensen George. Demokrasi dan Demokratisasi. Yogyakarta : Pustaka Pelajar. 2003. Soekanto , Soerjono dan Purnadi Purbacaraka. Perihal Kaidah Hukum. Bandung: PT. Citra Aditya Bakti, 1993. hlm 92

Sunggono, Bambang, Metodelogi Penelitian Hukum. PT Raja Grafindo Persada: Jakarta 2003.

Surbakti, Ramlan, Memahami Ilmu Politik, Jakarta, Jakarta: Grasindo, 1992.

Suleman, Zulfikri, Demokrasi untuk Indonesia, Pemikiran Politik Bung Hatta. Jakarta. Penerbit Kompas, 2010.

Sulaiman, King, Faisal. Teori Peraturan Perundnag-Undangan Dan Aspek Pengujian. Cetakan Ke-1, Januari 2017.

Supriadi, Etika dan Tanggung Jawab Profesi Hukum Di Indonesia, Jakarta, Sinar Grafika, Cetakan ketiga 2010.

Tafsir, Ahmad. Filsafat Umum. Cet. VI; Bandung: PT Remaja Rosdakarya, 1998.

Tauda, Gunawan A. Komisi Negara Independen Eksistensi Independent Agencis Sebagai Cabang Kekuasaan Baru Dalam Sistem Ketatanegaraan. GENTA Press, Yogyakarta. 2012

\section{B. Artikel/ Makalah}

ACE Electoral Knowledge Network. The ACE Encyclopaedia : Electoral Integrity, 2013. hlm 1-204. Analisis Tata Kelola Pemilukada dalam Perspektif Electoral 
Integritydi Kota Yogyakarta Tahun 2017. Dalam Naskah Publikasi. Riska, Sarofah dan Titin. Purwaningsih.

Alesita, Oshit, Et al. Evaluasi Proses Verifikasi Calon Anggota Legislatif Pada Pemilihan Umum Legislatif 2014 - 2019. Jurnal. Jurusan Ilmu Pemerintahan Fakultas Ilmu Sosial dan Politik Universitas Deponegoro. 2019.

Aziz, Noor M. Laporan Akhir pengkajian Hukum Tentang Pemilihan Kepala Daerah. Badan Pembinaan Hukum Nasional Kemenyrian Hukum dan HAM Republik Indonesia. 2009.

Bisarida Et al. Komparasi Mekansime Penyelasaian Sengketa Pemilu di Beberapa Negara Penganut Paham Demokrasi. Jurnal Konstitusi, Vol. 9, Nomor 3, 2012, hlm.538

Fahmi. Khairul, Menelusuri Konsep Keadilan Pemilihan Umum, Menurut UndangUndang Dasar Negara Republik Indonesia Tahun 1945. Jurnal Cita Hukum. 2016.

Frenki. Asas-Asas Dalam Pelaksanaan Pemilihan Umumdi Indonesia Menurut Fiqh Siyasah. Jurnal. Fakultas Syariah IAIN Raden Intan Lampung.

Gleko, P. Suprojo, A. dan Lestari, A.W. Strategi Komisi Pemilihan Umum Dalam Upaya Meningkatkan Partisipasi Politik Masyarakat Pada Pemilihan Umum Kepala Daerah. Jurnal Ilmu Sosial dan Ilmu Politik. 2017.

Haryanti, Dewi. Konstruksi Hukum Lembaga Penyelenggara Pemilihan Umum di Indonesia Ditinjau dari Teori Stufenbau. Jurnal Dosen Fakultas Hukum Universitas Maritim Raja Ali Haji UMRAH. 2015 tanggal 17 Februari 2020.

James, T. S. (n.d.). Building Better Elections : The Role of Human Resource Management Practices, 2017. Analisis Tata Kelola Pemilukada dalam Perspektif Electoral Integritydi Kota Yogyakarta Tahun 2017. Dalam Naskah Publikasi. Riska, Sarofah dan Titin. Purwaningsih.

Lati Praja Delmana, Aidinil Zetra dan Alfan Miko. Konstruksi Indikator dan Formula Penilaian Kualitas Pemilihan Umum di Indonesia. Universitas Andalas Indonesia. Jurnal Ilmu Pemerintahan dan Sosial Politik. Juni 2019.

Luthfi Widagdo Eddyono. Penyelesaian Sengketa Kewenangan Lembaga Negara Oleh Mahkamah Konstitusi. Jurnal Konstitusi Volume 7, Nomor 3, Bulan Juni 2010, Terdapat Dalam https://media.neliti.com /media/ publications/110648-IDpenyelesaian-sengketa- kewenanganlembaga. pdf, Diakses Tanggal 16 Maret 2010.

Ratna Herawati, Novira Maharani S, Untung Dwi H. Kepastian Hukum Pemilu dalam Pemilu Serentak 2019 Melalui Peraturan Komisi Pemilihan Umum Republik Indonesia. Jurnal. Fakultas Hukum Universitas Diponegoro. Volume 4 Nomor 3 Tahun 2018.

Safira, Martha Eri, Analisis Pendekatan Teori Keadilan John Rawls dan Teori Moralitas Immanuel Khan Terhadap Caleg Mantan Narapidana Yang Lolos 
Sebagai Anggota Legislatif Dalam Pemilu 2019. Jurnal IAIN Ponorogo. Vol. 3 No.1, Maret 2019.

Soemantri, M Sri. Sistem Pemilu dalam Ketatanegaraan Indonesia. Majalah Persahi. Nomor tiga. Januari 1990. Dalam buku Ni'Matul Huda, N.Imam nasef. Penataan Dekrasi dan Pemilu di Indonesia Pasca Reformasi. Kencana. 2017.

Subono, Nur Imam. Et. al. Pembekalan Calon Anggota Legislatif. Kementrian Pemberdayaan Perempuan dan Anak. Modul. Republik Indonesia. 2017.

Syawawi, Reza dan Khoirunnisa Nur Agustyati, "Membunuh Demokrasi Lokal, Mengembalikan Pemilihan Gubernur kepada DPRD Provinsi“. Jurnal Pemilu dan Demokrasi, 2012.

Syaiful, Mohammad A, "Penataan Sistem Pemilihan Umum yang Berkeadilan untuk Penguatan Sister Presidensil di Indonesia". Fakultas Hukum Universitas Airlangga. Jurnal Penataan Sistem Pemilihan. Volume 33 No 2. Mei 2018

Umar Hasbi. Paradigma Baru Demokrasi di Indonesia: Pendekatan terhadap Pemilu DPR/DPRD ,Jurnal Innovatio Vol.VII, No.14 Edisi Juli-September 2008.

Yuliani, Widianingsih, "Demokrsi dan Pemilu di Indonesia" Dosen Fakultas Ilmu Sosial dan Ilmu Politik UPN "Veteran" Jakarta. Jurnal Demokrasi Pemilih, 2017.

\section{C.Peraturan Perundang-Undangan}

Undang-Undang Dasar Negara Republik Indonesia tahun 1945.

Undang-Undang Negara Republik Indonesia Nomor 15 Tahun 2011 tentang Penyelenggara Pemilu

Undang-Undang Negara Republik Indonesia Nomor 6 Tahun 2014 tentang Desa

Undang-Undang Negara Republik Indonesia Nomor 7 Tahun 2017 tentang Pemilihan Umum.

Peraturan Komisi Pemilihan Umum Nomor 20 Tahun 2018 tentang Pencalonan Anggota Dewan Perwakilan Rakyat, Dewan Perwakilan Rakyat Daerah Provinsi dan Dewan Perwakilan Rakyat Daerah Kabupaten/ Kota.

\section{D.Internet}

Apdesi, Asosiasi Pemerintah Desa Seluruh Indonesia. https://www.kabar-banten. com/apdesi- gugat-aturan- yang-jegal-kepala- desa-untuk-jadi-anggota -dprd/. diakses pada tanggal 31 Desembr 2019.

Aziz Hakim Muhammad, Politik Hukum Sistem Pemilihan Umum di Indonesia pada Era Reformasi Tesis Universitas Indonesia pada tahun 2012. file:///C:/U sers/App Data/ Local/Temp/ digital_20283450-29436 Politik 20hukum -2.pdf. diakases pada tanggal 11 Desember 2019.

Didik, Supriyanto https:// rumahpemilu. org/ catatan-proses-dan-hasil-pembahasanuu-pemilu/. diakses tanggal 24 Februari 2020. 
Hanan Djayadi, Memperkuat Presidensialisme Multipartai Di Indonesia: Pemilu Serentak, Sistem Pemilu Dan Sistem Kepartaian' 2017 http:// puskapol.ui.ac.id accessed. Diakses pada tanggal 17 Februari 2020.

Hasugian Tohap, Strategi Komisi Pemilihan Umum Dalam Meningkatkan Partisipasi Pemilih Studi Pada Pemilih Pemula, Perempuan dan Kelompok Marjinal pada Pemilihan Bupati dan Wakil Bupati 2018 di Kabupaten Dairi Provinsi Sumatera Utara. Tesis Universitas Lampung tahun 2019. http://digilib.unila.ac.id/56237/3/tesis\%20 tanp a\%20 bab\%20pembahasan .pdf. diakses pada tanggal 26 desember 2019.

https://kpu.go.id/index.php/pages/index/hvNapiPYxk4sdYH3xzU_ BM80gPYcL CQre4Ky3AZRPBWlk_Wkch7gfRYZy04sB0lky0Ej7b115BEe3heU6XuIdA. diakses pada tanggal 22 Februari 2020.

https://sejarahlengkap. com/indonesia/ sejarah-pemilu-di-indonesia diakses tanggal 21 Februari 2020.

Landasan Teori. com/2015/10/ Pengertian-Pemilihan- Umum-Fungsi-Sistem. http:// www. diakses pada tanggal 17 Februari 2020.

Pengertian, Fungsi dan Sistem Pemilihan Umum. http://diy.kpu.go.id.web /2016/12/19/ Pengertian-Fungsi-dan-Sistem- Pemilihan-Umum/ diakses pada tanggal 22 Februari 2020.

Rahmat Hidayat. Pengertian Pemilu, Tujuan dan Asa Pemilu. Htt://www. kitapnya. net/ 2106. Pengertian-Pemilu- Tujuan-dan-Asas-Pemilu. Html di akses pada tanggal 22 Februari 2020.

https://www.slideshare.net/ahsanov/memahami-uu-7-tahun-2017. diakses tanggal 24 Februari 2020.

Standar, Internasional Kelembagaan Penyelenggara Pemilu", www.rumah pemilu. Org. diakses pada tanggal 28 November 2019.

Wibowo, Arif Teori Keadilan John Rawls. dalam https://staff.blog.ui.ac.id/ arif51/ 2008/12/01/teori-keadilan-john-rawls/. diakses pada tanggal 18 Februari 2020.

Zaini, Hukum pada Pelaksanaan Pemungutan dan Penghitungan Suara Pemilu anggota DPR, DPD, dan DPRD tahun 2014 di Kabupaten Pemekasan Tesis Universitas Narotama Surabaya tahun 2015. http://repository. narotama. ac.id/214/2/tesis\%20zaini.pdf. 11 Desember 2019. 